\title{
Do Covenants of Bonds Outstanding Affect the Choice of Covenants of New Issues? Evidence from the U.S. Corporate Bonds
}

\author{
Yuqian Wang ${ }^{1,2}$, Che-Wei Chiu ${ }^{1,2} \&$ Mark Wrolstad ${ }^{1}$ \\ ${ }^{1}$ College of Business, Winona State University, Winona, MN, USA \\ ${ }^{2}$ Naveen Jindal School of Management, University of Texas at Dallas, Richardson, TX, USA \\ Correspondence: Yuqian Wang, College of Business, Winona State University, Winona, MN, USA
}

Received: December 12, 2017

Accepted: January 9, 2018

Online Published: January 11, 2018

doi:10.5430/afr.v7n1p223

URL: https://doi.org/10.5430/afr.v7n1p223

\begin{abstract}
This paper investigates the relation between debt covenants of a firm's bonds outstanding and covenants of its newly issued bonds. On the one hand, since covenants are priced and costly, newly issued bonds may not include covenants that have been used in bonds outstanding, suggesting a negative relation between covenants of bonds outstanding and those of new issues. On the other hand, since firms tend to use boilerplate language in debt indentures, similar covenants of bonds outstanding are likely to be used repeatedly in the contracts of new issues, indicating a positive relation. Based on the U.S. public corporate bonds data from 1990 to 2014, this paper provides empirical evidence that covenants of a firm's new issues are positively related to covenants of its bonds outstanding, suggesting boilerplate language is widely used in corporate bond contracts. Results also show that use of boilerplate language is significantly related to issuers' financial condition and economic cycle. Issuers with stable financial condition, as measured by commercial paper ratings, tend to use boilerplate language more frequently. And during the Dot-Com bubble period, boilerplate language is used more prevalently than during the financial crisis period.
\end{abstract}

Keywords: Bond covenants, Dot-Com bubbles, Financial crisis, Boilerplate language

\section{Introduction}

Restrictive covenants are widely used in debt contracts. Jensen and Meckling (1976), Myers (1977) and Smith and Warner (1979) suggest that debt covenants could restrict the behavior of firm managers and mitigate the agency problem between shareholders and creditors. In other words, covenants can protect creditors, and more covenants provide more protection. However, covenants come with costs. As pointed out by Jensen and Meckling (1976), the optimal set of covenants is determined by balancing the incentive achievements against all kinds of costs of implementing the debt agreement. Recent studies provide empirical evidence that covenants are priced; that is, lenders have to accept a lower interest rate when include more covenants in the debt contract. Bradley and Roberts (2015) document a negative relation between the promised yield of bank loans and the presence of covenants. Reisel (2014) finds that the restriction on investment or issuance of higher priority claims can reduce the cost of public debt. This leads to the research question of this study: if covenants are costly, will covenants of a firm's debt outstanding be used repeatedly in the firm's new debt issues?

Covenants in one debt issue provide protection not only for creditors of that issue, but also for other creditors of the same firm. Therefore, creditors may use fewer covenants in new issues and save costs when the firm has been restricted by similar covenants of debt outstanding. In other words, covenants of debt outstanding could substitute for covenants of new debt issued by the same firm. On the other hand, in the public corporate bond market, debt indentures are generally set by an issuing firm and its investment banker. They are likely to use boilerplate language (Simpson, 1973); a standard provision in a bond contract could be used over and over without much change. In this case, covenants of bonds outstanding can be carried over to new issues, suggesting a positive relation between covenants of bonds outstanding and covenants of new issues. Taken together, the relation between the two is an empirical question.

To investigate the effects of existent bond covenants on the choice of covenants of new issues, we collect covenant information from Mergent Fixed Income Securities database (FISD). After merged with firm characteristics from COMPUSTAT, our final sample contains 4204 public bonds issued by 950 unique U.S. nonfinancial and unregulated firms over the period 1990 to 2014. 
We classify forty-six bond covenants into four categories: dividend covenants, financing covenants, investment covenants and event covenants (Chava, Kumar, and Warga, 2010; Billett, King, and Mauer, 2007; and Smith and Warner, 1979). Applying OLS models, ordinal probit models and probit models, we find consistent evidence that covenants of new issues are positively related to covenants of bonds outstanding of the same firm, and the positive relation is more significant for firms with commercial paper ratings. Our findings support the hypothesis that boilerplate language is widely used in public corporate bond market. These results also indicate that firms with good financial health, as indicated by the presence of commercial paper ratings, tend to use boilerplate language more frequently in bond indentures.

On the other hand, our findings do not support the substitution effect hypothesis. This suggests that the cost of including existent covenants of bonds outstanding to new issues is likely to be much lower than the cost of using new covenants. In other words, the pricing effects of "new" and "existent" covenants are likely to be different.

In addition, we find that the positive relation between covenants of bonds outstanding and covenants of new issues is more significant during the Dot-Com bubble period 1995-2000, and is much weaker during the financial crisis period 2007-2008. This finding indicates that debt contracts are more likely to be renegotiated and covenants are more likely to be modified during economic recession. Finally, we investigate the relation separately for each category of covenants, and find that the presence of dividend covenants, investment covenants, and event covenants in bonds outstanding significantly increases the probability of use of the same type of covenants in new issues by $13.1 \%, 30.5 \%$ and $20.3 \%$, respectively.

This paper extends the empirical literature on bond covenants along different dimensions. First, we contribute to research on covenant structure by showing that covenants of bonds outstanding are an additional important determinant of the choice of covenants of newly issued bonds. Prior studies generally find presence of covenants is negatively related to the financial health of a firm. For example, Malitz (1986) finds large firms with low leverage are less likely to use covenants. Begley and Feltham (1999) document a positive relation between managerial ownership and presence of covenants. Different from prior studies, this paper examines the relation of covenants between bonds outstanding and new issues, and finds significantly positive relation between them. To the best of our knowledge, this is the first study that provides direct empirical evidence on interactions of bond covenants.

Secondly, this paper sheds light on the pricing effect of bond covenants. Previous studies find that certain types of covenants can significantly reduce the cost of bonds. For example, Crabbe (1991) finds use of event-risk covenants can decrease interest costs by 20 to 30 basis points. Torabzadeh, Roufagalas, and Woodruff (2000) find inclusion of a poison put provision reduces the yield by 58 to 78 basis points. Reisel (2014) finds that restriction on investment or issuance of higher priority claims can reduce the cost of public debt. However, prior studies do not consider potentially different pricing effects of "new" and "existent" covenants. Evidence in our paper suggests that the real cost of carrying over existent covenants of bonds outstanding to new issues is marginal compared to the cost of using new covenants. Given our findings, future research investigating the pricing effects of covenants should consider the differential pricing effects of new and existent covenants.

The rest of the paper proceeds as follows. Section 2 develops two hypotheses on effects of existent bond covenants on the choice of covenants in new issues. Section 3 describes the data and the empirical test design. Section 4 discusses the results. Section 5 is the robustness test and Section 6 concludes.

\section{Hypothesis Development}

In their seminal paper, Jensen and Meckling (1976) point out stockholders can expropriate the wealth of bondholders. Debt covenants could be used to restrict the behavior of firm managers, presumably mitigating the agency problem between shareholders and bondholders. Based on the theoretical work of Jensen and Meckling (1976), Smith and Warner (1979) argue that restrictions imposed by covenants are costly to the firm; as such, they must confer some offsetting benefits, i.e., the reduction in cost of debt. This argument suggests that covenants are being priced. The more constraining the covenants are, the lower debt yield creditors have to accept. Recent studies provide empirical evidence for the pricing effects of covenants. Bradley and Roberts (2015) document a negative relation between the promised yield on corporate debt issues and the presence of covenants. Reisel (2014) finds that restriction on investment or issuance of higher priority claims of nonbank public debt can reduce the yield.

Meanwhile, covenants of a debt issue provide protection not only for creditors of that particular issue, but also for other creditors of the same firm. For example, when a firm has an investment covenant that restrains managers from investing in high-risk projects, creditors of new issues also benefit from this covenant even if the same covenant is not included by new issues. Hence, considering the protection by existent covenants of bonds outstanding and the 
potential negative effect of covenants of new issues on the bond yield, creditors of new issues are likely to reduce the use of covenants when similar covenants have already been used in bonds outstanding. That is, covenants of bonds outstanding can substitute for covenants of new bonds issued by the same firm. This leads to the following hypothesis:

\section{Substitution Effect Hypothesis: Bond covenants of new issues are negatively related to existent bond covenants.}

On the other hand, public corporate bond indentures are generally set by an issuing firm and its investment banker, and they tend to use boilerplate language (Simpson, 1973). Thus, a standard provision in a bond contract could be used repeatedly without much change. In this case, existent covenants are likely to be carried over into new debt contracts, suggesting a positive relation between covenants of bonds outstanding and covenants of new issues. This hypothesis is stated as follows:

\section{Boilerplate Effect Hypothesis: Bond covenants of new issues are positively related to existent bond covenants.}

Collectively, the substitution effect hypothesis predicts a negative relation between covenants of new issues and covenants of bonds outstanding, while the boilerplate effect hypothesis predicts a positive relation between the two. Taken together, their relation is an empirical question.

\section{Data and Empirical Test Design}

\subsection{Data}

Our empirical analysis employs data from the following sources. Quarterly financial information is collected from COMPUSTAT. Information related to bond issuance and covenant usage is from Mergent Fixed Income Securities database (FISD). Yields on 10 year-Treasury bond and a 6-month Treasury bill, matched to the month of bond issuance, are from Federal Reserve. Our primary variables of interest are debt covenant indexes that show how many types of debt covenants are included in bonds.

Our sample contains public corporate bonds issued by U.S. domiciled firms that are in the intersection of FISD and COMPUSTAT for the period 1990-2014. Firms in the financial industries and regulated utility industries are excluded. We also exclude bonds with missing covenant information in FISD, along with Yankee, Canadian, and foreign currency bonds. (Note 1) If a firm has multiple debt issues on the same date, only the representative debt issue, i.e., the issue with the largest offering size and longest maturity, is kept. Our final sample includes 4204 new bond issues by 950 unique firms. To make sure our results are not driven by a few influential outliers, we winsorize firm-specific factors at the $1^{\text {st }}$ and $99^{\text {th }}$ percentile levels of the full sample.

Inspired by Chava, Kumar, and Warga (2010), Billett, King, and Mauer (2007) and Smith and Warner (1979), we classify forty-six bond covenants into four categories: dividend covenants, financing covenants, investment covenants and event covenants. (Note 2) A bond is coded as having a dividend covenant if the bond's indenture contains dividend restrictions or any other payment restrictions. A bond is coded as having a financing covenant if the bond's indenture contains at least one of the following restrictions: restrictions on debt (Note 3), debt priority (Note 4), sale and lease obligations, or stock issuance. A bond is coded as having an investment covenant if the bond's indenture contains restriction on direct (Note 5), indirect (Note 6) investment restrictions, or consolidation or mergers. A bond is coded as having an event covenant if the bond's indenture contains default-related event covenants (Note 7) or change of control provision-poison put. Bond restrictions on a firm and on its subsidiaries are considered.

We then construct dummy variables for new bond issues to indicate each of the four categories of covenants. Specifically, a dividend covenant dummy is equal to one if dividend covenants exist in the new issue's indenture, and is equal to zero otherwise. Financing covenant dummy, investment covenant dummy and event covenant dummy are constructed in the same way. Next, we define the covenant index of a new issue as the sum of four covenant dummies. It takes the discrete values 0 to 4 and represents the total of covenant categories written into a new issue's indenture. For each observation of new issues, we also construct the covenant dummies and covenant index of bonds outstanding in the same way. Take AES Corp. as an example. When AES Corp. issued a public bond in 2007 (i.e., the new issue), there were eight bonds outstanding. Three were issued in 2001, two were issued in 1998, and one was issued in 1999, 2000 and 2004 respectively. The covenant index of the new issue is equal to one since the new issue in 2007 has only event covenants; the index of bonds outstanding is equal to four since four categories of covenants are present in the indentures of the eight bonds outstanding (i.e., bonds issued in 1998, 1999, 2000, 2001 and 2004).

Panel A of Table 1 reports the summary statistics of covenant dummies and covenant indexes for both new issues and bonds outstanding. As shown in Panel A of Table 1, 23.1\% of new issues have dividend covenants written in the 
indenture, $93.7 \%$ have financing covenants, $89.3 \%$ have investment covenants and $79.2 \%$ have event covenants. The corresponding percentages for bonds outstanding are $31.8 \%, 97.4 \%, 95.2 \%$ and $86.4 \%$, respectively. Our sample shows that financing covenants are the most widely used in a debt's indenture, followed by investment covenants. In addition, the covenant index shows that new bond issues on average have 2.85 categories of covenants, while bonds outstanding have 3.11 categories.

Panel B and Panel C of Table 1 report the mean of covenant index for subsamples. In Panel B, the full sample is partitioned by firms' credit ratings. As shown in Panel B, the mean of covenant index is lower for firms with good credit ratings, suggesting that firms with lower default risk on average use fewer types of covenants in their bond indentures. In Panel C, the mean of covenant index is reported separately for firms with and without commercial paper ratings. Results in Panel C show that, on average, firms with commercial paper ratings have fewer types of covenants than firms without commercial paper ratings.

Table 1. Summary statistics of bond covenants

Panel A. Covenant characteristics for new issues and bonds outstanding (observations $=4204$ )

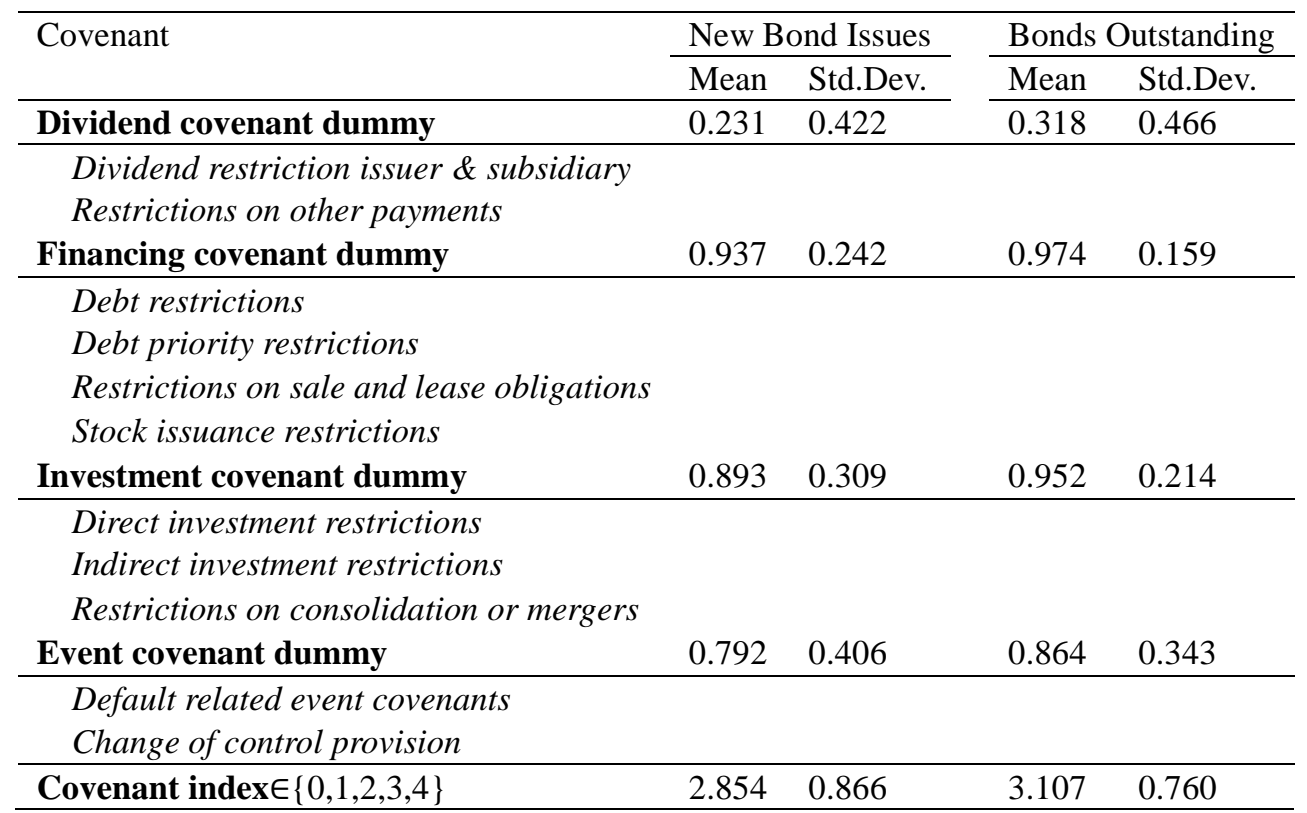

Panel B. The mean of covenant index for subsamples partitioned by firms' credit ratings

\begin{tabular}{lrrr}
\hline & & \multicolumn{2}{c}{ Covenant index } \\
\cline { 3 - 4 } & Observations & New Bond Issues & Bonds Outstanding \\
\hline AAA & 47 & 2.242 & 2.298 \\
AA & 281 & 2.538 & 2.516 \\
$\mathrm{~A}$ & 996 & 2.699 & 2.725 \\
$\mathrm{BBB}$ & 1299 & 3.340 & 2.975 \\
$\mathrm{BB}$ & 894 & 3.302 & 3.597 \\
$\mathrm{~B}$ & 619 & 3.000 & 3.567 \\
$\mathrm{CCC}$ & 49 & 2.889 & 3.571 \\
$\mathrm{CC}$ & 9 & 3.500 & 3.778 \\
$\mathrm{C}$ and below & 10 & 3.500 & 3.700 \\
\hline Total & 4204 & 2.854 & 3.107 \\
\hline
\end{tabular}

Panel C. The mean of covenant index for subsamples partitioned by commercial paper ratings

\begin{tabular}{lrrr}
\hline & & \multicolumn{2}{c}{ Covenant index } \\
\cline { 3 - 4 } & Observations & New Bond Issues & Bonds Outstanding \\
\hline With Commercial Paper Rating & 1964 & 2.510 & 2.758 \\
Without Commercial Paper Rating & 2240 & 3.155 & 3.413 \\
\hline Total & 4204 & 2.854 & 3.107 \\
\hline
\end{tabular}




\subsection{Model Specification}

We use the following regression model to examine the relation between covenants of new bond issues and covenants of bonds outstanding:

$$
\begin{aligned}
\text { Covnt index.new }= & \beta_{1} \text { Covnt index.existing }+ \text { Bond characteristics }+ \text { Firm characteristics } \\
& + \text { Macroeconomic factors }+ \text { Industry dummies }+ \text { Year dummies }+\varepsilon
\end{aligned}
$$

The dependent variable of Equation (1) is the covenant index of new issues. The coefficient, $\beta_{1}$, captures the relation of covenants of new issues and covenants of bonds outstanding. A positive coefficient supports the boilerplate effect hypothesis, while a negative coefficient supports the substitution effect hypothesis.

We control the effects of other bond characteristics, firm characteristics, and macroeconomic factors over time. Definitions of these control variables are detailed in Table 2. Additionally, we control industry effects and year effects by including industry dummies and year dummies. Industry dummies are based on Fama and French 48 SIC industry classifications.

Table 2. Definitions of control variables

\begin{tabular}{ll}
\hline Variable & Definition \\
\hline Bond characteristics &
\end{tabular}

Issue size (\%)

Longer maturity dummy

Secured

\section{Firm characteristics}

Firm size

Leverage

MB ratio

Fixed asset

Short-term debt

Abnormal earnings

Investment grade dummy

Commercial paper dummy

Macroeconomic factors

Term premium

Dotcom Bubble dummy

Crisis2008 dummy
The percentage of offering amount over total asset

A dummy variable, which equals one if the maturity of new bonds is longer than any other bonds with covenants outstanding, and equals zero otherwise

A dummy variable, which equals one if the new debt issue is secured, and equals zero otherwise

Logarithm of book value of assets (\$ in millions) [atq]

The book value of total debt [dlttq+dlcq] divided by the market value of assets, where the market value of assets is estimated as the book value of assets [at] minus the book value of equity [ceqq] plus the market value of equity [prcc_fq*cshoq]

The market value of assets divided by the book value of assets

The ratio of net property, plant, and equipment [ppentq] to the book value of total assets

Debt that matures within one year [dd1q] divided by total debt [ltq]

The difference between earnings per share [epsfxq] in year $t+1$ minus earnings per share in year $t$, divided by the year $t$ share price

A dummy variable, which equals one if a firm has an investment grade rating, and equals zero otherwise

A dummy variable, which equals one if a firm has a commercial paper rating, and equals zero otherwise

The difference between the month-end yields on a 10-year government bond and a 6-month government bill, matched to the month of the new issue. Bond yields are from the Federal Reserve Bank of St. Louis's economic database [FRED]

A dummy variable, which equals one if the new debt is issued during the Dot-Com bubbles from year 1995 to 2000, and equals zero otherwise

A dummy variable, which equals one if the new debt is issued during the financial crisis from year 2007 to 2008, and equals zero otherwise

Note: COMPUSTAT item codes are in the brackets. 
Table 3 provides descriptive statistics of the control variables. As shown in Table 3, the average size of new issues accounts for $7.42 \%$ of total assets. $42.6 \%$ of new issues have maturity longer than bonds outstanding. Firms in our sample generally have a big size; their total asset is \$20 622 million on average. 62.4\% of firms have an investment grade rating and $46.7 \%$ have a commercial paper rating. These characteristics are consistent with the finding by Denis and Mihov (2003) that public corporate bond issuers are usually big firms with good credit quality. Also, in our sample, 20.2\% of new bonds are issued during the Dot-Com bubble period 1995 to 2000, and 8.8\% are issued during the recent financial crisis period 2007 to 2008.

Table 3. Descriptive Statistics (observations $=4204$ )

\begin{tabular}{lrrrrr}
\hline Variable & Mean & Median & Std.Dev & p25 & \multicolumn{1}{c}{ p75 } \\
\hline Bond characteristics & & & & & \\
Issue size (\%) & 7.418 & 4.373 & 8.866 & 1.915 & 9.439 \\
Longer maturity dummy & 0.426 & 0 & 0.495 & 0 & 1 \\
Secured & 0.025 & 0 & 0.157 & 0 & 0 \\
Firm characteristics & & & & & \\
Firm size & 20622 & 7909 & 35684 & 2870 & 22285 \\
Leverage & 0.248 & 0.212 & 0.152 & 0.135 & 0.338 \\
MB ratio & 1.750 & 1.490 & 0.874 & 1.202 & 2.005 \\
Fixed asset & 0.378 & 0.334 & 0.253 & 0.163 & 0.568 \\
Short-term debt & 0.005 & 0 & 0.022 & 0 & 0 \\
Abnormal earnings & 0.002 & 0.000 & 0.062 & -0.006 & 0.005 \\
Investment grade dummy & 0.624 & 1 & 0.484 & 0 & 1 \\
Commercial paper dummy & 0.467 & 0 & 0.499 & 0 & 1 \\
Macroeconomic factors & & & & & \\
Term premium & 1.823 & 2.030 & 1.149 & 0.810 & 2.770 \\
Dotcom Bubble dummy & 0.202 & 0 & 0.402 & 0 & 0 \\
Crisis2008 dummy & 0.088 & 0 & 0.283 & 0 & 0 \\
\hline
\end{tabular}

We estimate Equation (1) by the ordinary least squares (OLS) model as well as the ordinal probit model. The ordinal probit model is applied since the dependent variable, covenant index of new issues is an integer between 0 and 4 (Note 8). Under the ordinal probit model, probabilities for each possible value of covenant index are given as follows,

$$
\begin{aligned}
& \text { Prob }(\text { Covnt index.new }=0)=\Phi\left(\mu_{0}-x^{\prime} \beta\right) \\
& \text { Prob }(\text { Covnt index.new }=1)=\Phi\left(\mu_{1}-x^{\prime} \beta\right)-\Phi\left(\mu_{0}-x^{\prime} \beta\right) \\
& \text { Prob }(\text { Covnt index.new }=2)=\Phi\left(\mu_{2}-x^{\prime} \beta\right)-\Phi\left(\mu_{1}-x^{\prime} \beta\right) \\
& \text { Prob }(\text { Covnt index.new }=3)=\Phi\left(\mu_{3}-x^{\prime} \beta\right)-\Phi\left(\mu_{2}-x^{\prime} \beta\right) \\
& \text { Prob }(\text { Covnt index.new }=4)=1-\Phi\left(\mu_{3}-x^{\prime} \beta\right)
\end{aligned}
$$

where $\Phi$ is the normal cumulative distribution function, $\mu_{1}, \mu_{2}, \mu_{3}, \mu_{4}$ are parameters to be estimated along with $\beta \mathrm{s}$, and $x^{\prime} \beta=\beta_{1}$ Covnt index.existing + All control variables.

Finally, we examine the relation between covenants of new issues and those of bonds outstanding for each covenant category by estimating Equation (2).

$$
\begin{aligned}
\text { Category dummy.new }= & \gamma_{1} \text { Dividend covnt dummy.existing }+\gamma_{2} \text { Financing covnt dummy.existing } \\
& +\gamma_{3} \text { Investment covnt dummy.existing }+\gamma_{4} \text { Event covnt dummy.existing } \\
& + \text { control variables }+\varepsilon
\end{aligned}
$$

In Equation (2) the dependent variable is one of the four category dummies of new issues: dividend covenant dummy, financing covenant dummy, investment covenant dummy, and event covenant dummy. These dummy variables indicate whether a firm has a specific category of covenants in new issues. Since the dependent variable is a binomial variable, Equation (2) is estimated using the probit model. The control variables in Equation (2) are exactly the same as those in Equation (1), i.e., bond characteristics, firm characteristics, macroeconomic factors, industry dummies 
and year dummies.

Under the probit model the probabilities of including each specific covenant category in new issues are as follows:

$$
\begin{aligned}
& \text { Prob ( Dividend covnt dummy=1) }=\Phi\left(x^{\prime} \gamma\right) \\
& \text { Prob ( Financing covnt dummy }=1)=\Phi\left(x^{\prime} \gamma\right) \\
& \text { Prob ( Investment covnt dummy }=1)=\Phi\left(x^{\prime} \gamma\right) \\
& \text { Prob ( Event covnt dummy }=1)=\Phi\left(x^{\prime} \gamma\right)
\end{aligned}
$$

where $\Phi$ is the normal cumulative distribution function, and

$$
\begin{aligned}
x^{\prime} \gamma= & \gamma_{1} \text { Dividend covnt dummy.existing }+\gamma_{2} \text { Financing covnt dummy.existing } \\
& +\gamma_{3} \text { Investment covnt dummy.existing }+\gamma_{4} \text { Event covnt dummy.existing } \\
& + \text { control variables. }
\end{aligned}
$$

We use the model to examine whether the likelihood of one specific type of covenants chosen in new issues is related to the presence of the same type of covenants in bonds outstanding. For example, when the dependent variable is Dividend covnt dummy.new, $\gamma_{1}$ captures the relation between dividend covenants of new issues and dividend covenants of bonds outstanding. The substitution effect hypothesis predicts $\gamma_{1}$ to be negative, while the boilerplate effect hypothesis predicts it to be positive.

\section{Empirical Analyses}

Table 4 presents the empirical results of Equation (1) estimated by the OLS model. Column 1 reports the results of the base model. We add an interaction term of covenant index and investment grade dummy in Column 2 , and an interaction term of covenant index and commercial paper dummy in Column 3. These interaction terms are added to the base model to examine whether the relation between covenants of new issues and covenants of bonds outstanding is different for firms with investment grade ratings and for firms with commercial paper ratings. Firms with investment grade ratings or commercial paper ratings generally have stable financial condition and are less risky, and thus their covenants are less likely to be binding. Finally, in Column 4, we add two dummy variables, Dotcom Bubble dummy and Crisis2008 dummy, and their interactions with covenant index to the base model. Dotcom Bubble dummy and Crisis2008 dummy are equal to one if new bonds are issued during the period 1995-2000 and period 2007-2008, respectively. The two interaction terms are added to examine whether the relation between covenants of new issues and covenants of bonds outstanding is also affected by economic cycle. Since these two dummy variables are a linear combination of year dummies, we do not add any other year dummies per se in Column 4 to prevent perfect multicollinearity.

As shown in Table 4, covenants of new bond issues are positively correlated with existent covenants in all of the four model specifications. In Column 1, when covenant index of bonds outstanding increases by one, covenant index of new issues increases by 0.30 , or by $10.48 \%$, as scaled by the sample average of covenant index of new issues $(0.299 / 2.854=10.48 \%)$. This supports our boilerplate effect hypothesis that boilerplate language is widely used in bonds' indentures; similar covenants of bonds outstanding are likely to be used again in new issues. Meanwhile, the positive relation is not consistent with the substitution effect hypothesis, suggesting that the cost of carrying over existent covenants into new bond indentures is likely to be low. In other words, the pricing effect of covenants as documented in prior research (e.g., Bradley and Roberts, 2015) could be different between existent covenants and new covenants. The pricing effect of existent covenants is likely to be much lower than that of new covenants. As a result, existent covenants are likely to be used repeatedly in the contracts of new issues. 
Table 4. Relation of existent covenants and covenants in new issues: OLS model

Dependent variable: Covenant index of new issues

\begin{tabular}{|c|c|c|c|c|}
\hline Dependent variable: $\mathrm{C}$ & $\begin{array}{l}\text { ant index } \\
\text { (1) }\end{array}$ & $\begin{array}{c}\text { new issues } \\
\text { (2) }\end{array}$ & (3) & (4) \\
\hline Covnt index.existing & $\begin{array}{l}0.299 * * * \\
(0.022)\end{array}$ & $\begin{array}{l}0.281 * * * \\
(0.038)\end{array}$ & $\begin{array}{l}0.235 * * * \\
(0.030)\end{array}$ & $\begin{array}{l}0.304 * * * \\
(0.026)\end{array}$ \\
\hline Covnt index.existing $\times$ Investment grade dummy & & $\begin{array}{c}0.033 \\
(0.046)\end{array}$ & & \\
\hline Covnt index.existing $\times$ Commercial paper dummy & & & $\begin{array}{l}0.184 * * * \\
(0.042)\end{array}$ & \\
\hline Covnt index.existing $\times$ Dotcom Bubble dummy & & & & $\begin{array}{l}0.122 * * * \\
(0.038)\end{array}$ \\
\hline Covnt index.existing $\times$ Crisis 2008 dummy & & & & $\begin{array}{l}-0.269 * * * \\
(0.072)\end{array}$ \\
\hline Issue size & $\begin{array}{c}0.004 * \\
(0.002)\end{array}$ & $\begin{array}{c}0.004 * \\
(0.002)\end{array}$ & $\begin{array}{c}0.004 * \\
(0.002)\end{array}$ & $\begin{array}{l}0.006 * * * \\
(0.002)\end{array}$ \\
\hline Longer maturity dummy & $\begin{array}{c}0.046^{*} \\
(0.025)\end{array}$ & $\begin{array}{c}0.048^{*} \\
(0.025)\end{array}$ & $\begin{array}{l}0.057 * * \\
(0.025)\end{array}$ & $\begin{array}{l}0.057 * * \\
(0.025)\end{array}$ \\
\hline Secured & $\begin{array}{l}-0.020 \\
(0.108)\end{array}$ & $\begin{array}{l}-0.021 \\
(0.108)\end{array}$ & $\begin{array}{l}-0.020 \\
(0.108)\end{array}$ & $\begin{array}{l}-0.018 \\
(0.108)\end{array}$ \\
\hline Firm Size & $\begin{array}{l}-0.103 * * * \\
(0.014)\end{array}$ & $\begin{array}{l}-0.103 * * * \\
(0.014)\end{array}$ & $\begin{array}{l}-0.099 * * * \\
(0.014)\end{array}$ & $\begin{array}{l}-0.087 * * * \\
(0.014)\end{array}$ \\
\hline Leverage & $\begin{array}{l}0.355^{* * * *} \\
(0.127)\end{array}$ & $\begin{array}{l}0.360 * * * \\
(0.127)\end{array}$ & $\begin{array}{l}0.379 * * * \\
(0.127)\end{array}$ & $\begin{array}{c}0.200 \\
(0.125)\end{array}$ \\
\hline$M B$ ratio & $\begin{array}{l}-0.040 * * \\
(0.018)\end{array}$ & $\begin{array}{l}-0.039 * * \\
(0.018)\end{array}$ & $\begin{array}{l}-0.033^{*} \\
(0.018)\end{array}$ & $\begin{array}{l}-0.038 * * \\
(0.018)\end{array}$ \\
\hline Fixed asset & $\begin{array}{l}-0.211 * * * \\
(0.075)\end{array}$ & $\begin{array}{l}-0.210 * * * \\
(0.075)\end{array}$ & $\begin{array}{l}-0.194 * * * \\
(0.075)\end{array}$ & $\begin{array}{l}-0.219 * * * \\
(0.075)\end{array}$ \\
\hline Short-term debt & $\begin{array}{l}-1.916^{* * * *} \\
(0.722)\end{array}$ & $\begin{array}{l}-1.924 * * * \\
(0.722)\end{array}$ & $\begin{array}{l}-1.991 * * * \\
(0.720)\end{array}$ & $\begin{array}{l}-0.720 \\
(0.644)\end{array}$ \\
\hline Abnormal earnings & 0.182 & 0.182 & 0.185 & 0.139 \\
\hline Investment grade dummy & $\begin{array}{l}-0.146 * * * \\
(0.039)\end{array}$ & $\begin{array}{l}-0.255 \\
(0.159)\end{array}$ & $\begin{array}{l}-0.171 * * * \\
(0.040)\end{array}$ & $\begin{array}{l}-0.175 * * * \\
(0.039)\end{array}$ \\
\hline Commercial paper dummy & $\begin{array}{l}-0.062^{*} \\
(0.032)\end{array}$ & $\begin{array}{l}-0.059 * \\
(0.032)\end{array}$ & $\begin{array}{l}-0.601 * * * \\
(0.129)\end{array}$ & $\begin{array}{l}-0.072 * * \\
(0.032)\end{array}$ \\
\hline Term premium & $\begin{array}{l}-0.001 \\
(0.026)\end{array}$ & $\begin{array}{l}-0.002 \\
(0.026)\end{array}$ & $\begin{array}{c}0.001 \\
(0.026)\end{array}$ & $\begin{array}{l}-0.016 \\
(0.013)\end{array}$ \\
\hline Dotcom Bubble dummy & & & & $\begin{array}{l}-0.463 * * * \\
(0.119)\end{array}$ \\
\hline Crisis2008 dummy & & & & $\begin{array}{l}0.738 * * * \\
(0.216)\end{array}$ \\
\hline $\begin{array}{l}\text { Industry dummies } \\
\text { Year dummies }\end{array}$ & $\begin{array}{l}\text { Yes } \\
\text { Yes }\end{array}$ & $\begin{array}{l}\text { Yes } \\
\text { Yes }\end{array}$ & $\begin{array}{l}\text { Yes } \\
\text { Yes }\end{array}$ & $\begin{array}{l}\text { Yes } \\
\text { No }\end{array}$ \\
\hline $\begin{array}{l}\text { Observations } \\
R \text {-squared }\end{array}$ & $\begin{array}{r}4204 \\
0.321\end{array}$ & $\begin{array}{c}4204 \\
0.321\end{array}$ & $\begin{array}{r}4204 \\
0.325\end{array}$ & $\begin{array}{r}4204 \\
0.307\end{array}$ \\
\hline
\end{tabular}

Note: Standard errors are in parentheses. We use $* * * * *$ and $*$ to denote significance at the $1 \%$ level, $5 \%$ level, and $10 \%$ level, respectively.

In Column 3 of Table 4 the coefficient of the interaction term between covenant index and commercial paper dummy is statistically significant and positive (coef. $=0.184$ ), suggesting the positive relation of covenants in new issues and bonds outstanding becomes more significant for issuers with commercial paper ratings. Since firms with commercial paper ratings are generally financially stable and are thus less risky, this result shows that boilerplate language is more extensively used when issuers are in good financial health.

It is not surprising that we find more significant boilerplate effect for firms with commercial paper ratings than those with investment grade ratings. In our sample, $96.43 \%$ of firms with commercial paper ratings are rated as investment grade. Firms with commercial paper ratings could be viewed as a subset of investment grade firms with more stable 
financial condition and lower risk, and therefore, boilerplate language effect is more significant for firms with commercial paper ratings. Meanwhile, the coefficients of investment grade rating and commercial paper rating per se remain negative in all the four model specifications, consistent with results shown in Panel B and C of Table 1 that firms with good credit quality on average use fewer types of debt covenants.

In our sample, 20.2\% of new bonds are issued during the Dot-Com bubble period 1995 to 2000 and $8.8 \%$ are issued during the recent financial crisis 2007 to 2008. The regression model in Column 4 includes the interaction terms between covenant index and time period dummies. As shown in column 4, the positive effect of existent covenants is significantly amplified during the Dot-Com bubble period (coef. $=0.122$ ), and is significantly mitigated during the recent financial crisis (coef. $=-0.269$ ). These results suggest that use of boilerplate language is related to the economic cycle. Specifically, boilerplate language is used more frequently during economic bubbles, and less frequently during economic recession periods.

Additionally, in all the model specifications of Table 4, the coefficients of Issue size and Longer maturity dummy are consistently positive and statistically significant. This indicates more covenants are used in a new bond issue if the new issue has a large size or if its maturity is longer than that of bonds outstanding. Also, new bond covenant index decreases with firm size but increases with firm leverage, which is consistent with Maliz (1986) who attributes the relation to higher ex-ante agency costs. We also show that firms with high market-to-book ratio use fewer covenants in new issues, which could be explained by Kahan and Yermack (1998) and Nash, Netter, and Poulsen (2003). They find that high-growth firms are less likely to have restrictive bond covenants since potential benefits of covenants are overwhelmed by costs. Lastly, we find negative relations between use of covenants and firms with more fixed assets and higher proportion of short-term debt. These firms have less agency conflict and thus use fewer covenants.

Table 5 presents the regression results of Equation (1) estimated using the ordinal probit model. The ordinal probit model is a generalization of the probit model to the case of more than two outcomes of an ordinal dependent variable. Since the dependent variable covenant index is an integer between 0 and 4, we estimate Equation (1) using ordinal probit model as an alternative to the OLS model. Panel A of Table 5 reports estimates of model coefficients and Panel B reports the marginal effects of covenant index of bonds outstanding for the four model specifications as reported in Column 1 to Column 4 of Panel A. Column 1 of Panel B shows that, when covenant index of bonds outstanding increases by one, the probability that new issues have four types of covenants increases by $8.98 \%$ and the probability that new issues have three types of covenants increases by $6.89 \%$. Meanwhile, the probabilities that new issues have two types and one type of covenants decrease by $9.83 \%$ and 5.79\%, respectively. Column 2 to 4 show similar results. In summary, when more types of covenants are included in bonds outstanding, more types of covenants are likely to be written into the new issues' indenture. These results from ordinal probit regression are consistent with results estimated by OLS models in Table 4, providing further support for the boilerplate effect hypothesis. 
Table 5. Relation of existent covenants and covenants in new issues: Ordinal probit model

Panel A: Ordinal probit regression results

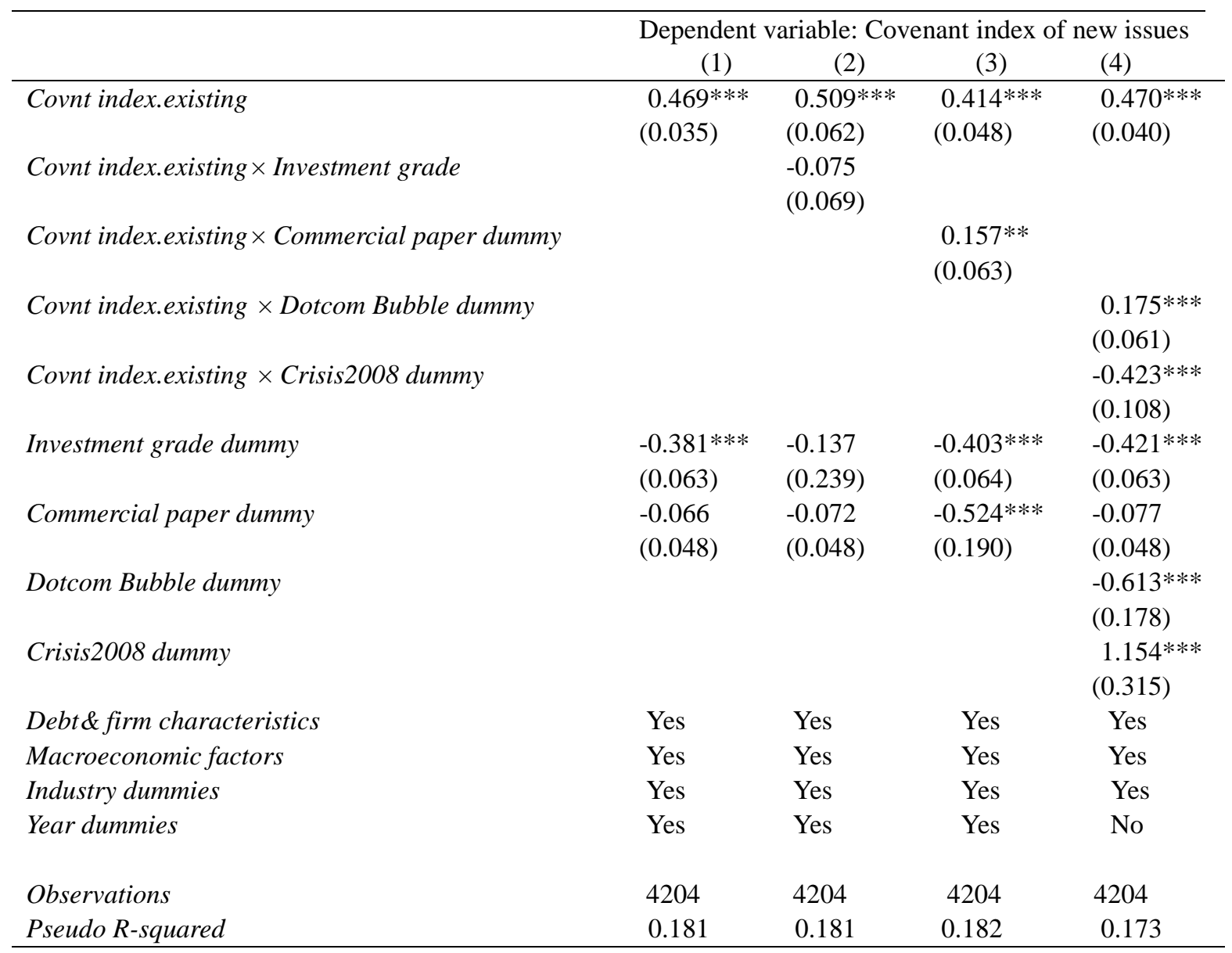

Note: Standard errors are in parentheses. We use $* * * * *$ and $*$ to denote significance at the $1 \%$ level, $5 \%$

Panel B. Marginal effects of covenant index of bonds outstanding on the choice of covenants in new issues estimated by ordinal probit model

\begin{tabular}{lcccc}
\hline & $(1)$ & $(2)$ & $(3)$ & $(4)$ \\
\hline Prob (Covnt index.new $=0)$ & $-0.25 \%$ & $-0.29 \%$ & $-0.20 \%$ & $-0.29 \%$ \\
Prob (Covnt index.new $=1)$ & $-5.79 \%$ & $-6.48 \%$ & $-4.86 \%$ & $-5.96 \%$ \\
Prob (Covnt index.new $=2$ ) & $-9.83 \%$ & $-10.61 \%$ & $-8.73 \%$ & $-9.70 \%$ \\
Prob (Covnt index.new $=3)$ & $6.89 \%$ & $7.85 \%$ & $8.64 \%$ & $6.84 \%$ \\
Prob (Covnt index.new $=4)$ & $8.98 \%$ & $9.54 \%$ & $8.14 \%$ & $9.12 \%$ \\
\hline
\end{tabular}

Next, we examine the relation of covenants of bonds outstanding and covenants of new issues for each covenant category separately. The results are shown in Table 6, where the marginal effects of probit model are reported. The dependent variables from Column 1 to 4 of Table 6 are dividend covenant dummy, financing covenant dummy, investment covenant dummy, and event covenant dummy of new issues, respectively. We find that when dividend covenant, investment covenant, and event related covenant are included in existing bond indentures, the probability of having the same category of covenants in new issues increases by $13.1 \%, 30.5 \%$, and $20.3 \%$, respectively. The effect of existent financing covenant is still positive, while not statistically significant. These results provide further empirical support for the boilerplate effect hypothesis that a particular category of covenants is more likely to be included in new bond issues if that category is included in the firm's bonds outstanding. 
Table 6. Marginal effects of different categories of existent covenants on the choice of covenants in new issues: Probit model

\begin{tabular}{lcccc}
\hline & $\begin{array}{c}(1) \\
\text { Dividend } \\
\text { covnt.new }\end{array}$ & $\begin{array}{c}\text { Financing } \\
\text { covnt.new }\end{array}$ & $\begin{array}{c}(3) \\
\text { Investment } \\
\text { covnt.new }\end{array}$ & $\begin{array}{l}\text { Event } \\
\text { covnt.new }\end{array}$ \\
\hline Dividend covnt.existing & $0.131^{* * *}$ & -0.001 & -0.001 & 0.012 \\
& $(0.009)$ & $(0.010)$ & $(0.013)$ & $(0.016)$ \\
Financing covnt.existing & $-0.092^{* * *}$ & 0.021 & $-0.206^{* * *}$ & 0.002 \\
& $(0.030)$ & $(0.029)$ & $(0.032)$ & $(0.045)$ \\
Investment covnt.existing & $0.084^{* * *}$ & $0.061^{* * *}$ & $0.305^{* * *}$ & $-0.042^{*}$ \\
& $(0.030)$ & $(0.023)$ & $(0.023)$ & $(0.026)$ \\
Event covnt.existing & 0.028 & -0.012 & -0.021 & $0.203 * * *$ \\
& $(0.025)$ & $(0.017)$ & $(0.016)$ & $(0.011)$ \\
Debt\& firm characteristics & Yes & Yes & Yes & Yes \\
Macroeconomic factors & Yes & Yes & Yes & Yes \\
Industry dummies & Yes & Yes & Yes & Yes \\
Year dummies & Yes & Yes & Yes & Yes \\
Observations & & & & \\
Pseudo R-squared & 4169 & 3935 & 4132 & 3839 \\
& 0.582 & 0.202 & 0.207 & 0.502
\end{tabular}

\section{Robustness Test}

In the robustness test, we use an alternative way to construct bond covenant index. First, forty-six different debt covenants are classified into the same four categories as before: dividend restrictions, financing restrictions, investment restrictions and event related restrictions. Next, within each category covenants are further classified into different subcategories. As shown in table 7, dividend covenants are classified into two subcategories: restrictions on dividend and restrictions on other payments. Financing covenants are classified into four subcategories: restrictions on debt, restrictions on debt priority, restrictions on sale and lease obligations, and restrictions on stock issues. Investment covenants are classified into three subcategories: restrictions on direct investment, restrictions on indirect investments, and restrictions on consolidation or mergers. Event related covenants are classified into two subcategories: default related event covenants and change of control provision. As such, all forty-six covenants are classified into eleven subcategories. Eleven dummy variables are constructed to indicate the existence of each of the covenant subcategories. The covenant index is the sum of dummy variables and it takes the value 0 to 11 .

Based on the alternative classification of bond covenants, we re-examine the relation between covenants of bonds outstanding and covenants of new issues using the OLS model. As shown in Table 8, we find results consistent with results of Table 4. Specifically, covenants of new bond issues are positively correlated with existent covenants in all model specifications. Column 2 shows that the positive relation of covenants in new issues and bonds outstanding is more significant for issuers with commercial paper ratings. Column 3 shows that the positive effect of existent covenants is significantly stronger during the Dot-Com bubble period, and is significantly mitigated during the recent financial crisis. In summary, empirical results of Table 8 provide further support for the boilerplate hypothesis and show that the positive relation between covenants of bonds outstanding and covenants in new issues is robust to different covenant classification schemes. 
Table 7. Alternative classification of public bond covenants (observation $=4204)$

\begin{tabular}{|c|c|c|c|c|}
\hline \multirow[t]{2}{*}{ Covenant } & \multicolumn{2}{|c|}{ New Bond Issues } & \multicolumn{2}{|c|}{ Bonds Outstanding } \\
\hline & Mean & Std.Dev. & Mean & Std.Dev. \\
\hline \multicolumn{5}{|l|}{ Dividend restriction: } \\
\hline Dividend restriction issuer \& subsidiary & 0.198 & 0.399 & 0.302 & 0.459 \\
\hline Restrictions on other payments & 0.216 & 0.412 & 0.283 & 0.451 \\
\hline \multicolumn{5}{|l|}{ Financing restriction: } \\
\hline Debt restrictions & 0.768 & 0.422 & 0.876 & 0.330 \\
\hline Debt priority restrictions & 0.919 & 0.272 & 0.961 & 0.193 \\
\hline Restrictions on sale and lease obligations & 0.145 & 0.352 & 0.224 & 0.417 \\
\hline Stock issuance restrictions & 0.054 & 0.227 & 0.127 & 0.333 \\
\hline \multicolumn{5}{|l|}{ Investment restriction: } \\
\hline Direct investment restrictions & 0.021 & 0.145 & 0.053 & 0.223 \\
\hline Indirect investment restrictions & 0.369 & 0.483 & 0.409 & 0.492 \\
\hline Restrictions on consolidation or mergers & 0.884 & 0.320 & 0.946 & 0.226 \\
\hline \multicolumn{5}{|l|}{ Event restriction: } \\
\hline Default related event covenants & 0.755 & 0.430 & 0.842 & 0.365 \\
\hline Change of control provision & 0.543 & 0.498 & 0.615 & 0.487 \\
\hline Covenant index $\in\{0,1,2,3,4,5,6,7,8,9,10,11\}$ & 4.873 & 2.346 & 5.639 & 2.378 \\
\hline
\end{tabular}

Table 8. Relation of existent covenants and covenants in new issues based on alternative covenant index

\begin{tabular}{|c|c|c|c|}
\hline \multicolumn{4}{|c|}{ Dependent variable: Alternative covenant index of new issues } \\
\hline & (1) & (2) & (3) \\
\hline Alternative Covnt index.existing & $\begin{array}{l}0.309^{* * *} \\
(0.020)\end{array}$ & $\begin{array}{l}0.277 * * * \\
(0.023)\end{array}$ & $\begin{array}{l}0.317 * * * \\
(0.022)\end{array}$ \\
\hline Alternative Covnt index.existing $\times$ Commercial paper dummy & & $\begin{array}{l}0.166 * * * \\
(0.039)\end{array}$ & \\
\hline Alternative Covnt index.existing $\times$ Dotcom Bubble dummy & & & $\begin{array}{l}0.101^{* * * *} \\
(0.033)\end{array}$ \\
\hline Alternative Covnt index.existing $\times$ Crisis2008 dummy & & & $\begin{array}{l}-0.163 * * * \\
(0.063)\end{array}$ \\
\hline Investment grade dummy & $\begin{array}{l}-0.693^{* * *} \\
(0.103)\end{array}$ & $\begin{array}{l}-0.730 * * * \\
(0.104)\end{array}$ & $\begin{array}{l}-0.731 * * * \\
(0.105)\end{array}$ \\
\hline Commercial paper dummy & $\begin{array}{c}0.088 \\
(0.072)\end{array}$ & $\begin{array}{l}-0.717 * * * \\
(0.195)\end{array}$ & $\begin{array}{c}0.062 \\
(0.074)\end{array}$ \\
\hline Dotcom Bubble dummy & & & $\begin{array}{l}-0.683 * * * \\
(0.179)\end{array}$ \\
\hline Crisis2008 dummy & & & $\begin{array}{l}0.609 * * \\
(0.303)\end{array}$ \\
\hline Debt\& firm characteristics & Yes & Yes & Yes \\
\hline Macroeconomic factors & Yes & Yes & Yes \\
\hline Industry dummies & Yes & Yes & Yes \\
\hline Year dummies & Yes & Yes & No \\
\hline Observations & 4204 & 4204 & 4204 \\
\hline Pseudo R-squared & 0.429 & 0.432 & 0.413 \\
\hline
\end{tabular}

Note: Standard errors are in parentheses. We use $* * * * *$ and $*$ to denote significance at the $1 \%$ level, $5 \%$ level, and $10 \%$ level, respectively. 


\section{Conclusions}

In this paper, we investigate the relation between covenants of a firm's bonds outstanding and covenants of its new bond issues. Based on a sample of 4204 public corporate bond issues during the period 1990 to 2014, we find robust evidence that bond covenants of new issues are positively related to those of bonds outstanding. This finding is consistent with the boilerplate effect hypothesis that covenants in corporate bond indentures are used repeatedly without much change. We also show that the boilerplate effect is more significant for firms with more stable financial condition, as measured by commercial paper ratings. Furthermore, we find that use of boilerplate language is related to the economic cycle by showing that the positive effect is more significant during the Dot-Com bubble period 1995-2000, and is much weaker during the financial crisis period 2007-2008. It suggests that during economic recession covenants of new contracts are more likely to be revised.

On the other hand, our empirical results do not support the substitution effect hypothesis that covenants of a firm's bonds outstanding substitute for covenants of the firm's new issues. Hence, another important implication of our finding is that the real cost of carrying over existent covenants of bonds outstanding to new issues is marginal compared to the cost of using new covenants. Recent studies provide empirical evidence of the pricing effects of covenants (e.g., Bradley and Roberts, 2015). However, these studies do not distinguish "new" covenants from "existent" covenants. Our findings suggest that the pricing effects of covenants on new bond issues is much weaker if these covenants have been used in the issuer' bonds outstanding. Hence, future research investigating the pricing effects of covenants should consider the effects of new and existent covenants separately.

\section{Acknowledgements}

We appreciate helpful comments from David Mauer and workshop participants at University of Texas at Dallas.

\section{References}

Begley, J. \& Feltham, G. (1999). An empirical examination of the relationship between debt contracts and management incentives. Journal of Accounting and Economics, 27, 229-259. https://doi.org/10.1016/S0165-4101(99)00006-3

Billett, M., King, T. \& Mauer, D. (2007). Growth opportunities and choice of leverage, debt maturity, and covenants. Journal of Finance, 62, 697-730. http://doi.org/10.1111/j.1540-6261.2007.01221.x

Bradley, M. \& Roberts, M. (2015). The structure and pricing of corporate debt covenants. Quarterly Journal of Finance, 05, 1-37. https://doi.org/10.1142/S2010139215500019

Crabbe, L. (1991). Event risk: An analysis of losses to bondholders and "Super poison put" bond covenants. The Journal of Finance, 46, 689-706. http://doi.org/10.1111/j.1540-6261.1991.tb02680.x

Chava, S., Kumar, P. \& Warga, A. (2010). Managerial Agency and Bond Covenants. Review of Financial Studies, 23, 1120-1148. https://doi.org/10.1093/rfs/hhp072

Denis, D.J. \& Mihov,V.,T. (2003). The choice among bank debt, non-bank private debt, and public debt: evidence from new corporate borrowings. Journal of Financial Economics, 70, 3-28. https://doi.org/10.1016/S0304-405X(03)00140-5

Jensen, M. (1986). Agency costs of free cash flow, corporate finance, and the market for takeovers. American Economic Review, 76, 323-329.

Jensen, M. \& W. Meckling (1976). Theory of the firm: Managerial behavior, agency costs and ownership structure. Journal of Financial Economics, 3, 305-360. https://doi.org/10.1016/0304-405X(76)90026-X

Kahan, M. \& Yermack, D. (1998). Investment opportunities and the design of debt securities. Journal of Law, Economics, and Organization, 14, 136-151. https://doi.org/10.1093/oxfordjournals.jleo.a023394

Malitz, I. (1986). On financial contracting: The determinants of bond covenants. Financial Management Summer, 18-25. https://doi.org/10.2307/3664974

Myers, S. (1977). Determinants of corporate borrowing. Journal of Financial Economics, 5, 147-175. https://doi.org/10.1016/0304-405X(77)90015-0

Nash, C. R., Netter, J. M. \& Poulsen, A. B. (2003). Determinants of contractual relations between shareholders and bondholders: investment opportunities and restrictive covenants. Journal of Corporate Finance, 9, 201-232. https://doi.org/10.1016/S0929-1199(02)00007-X

Reisel, N. (2014). On the value of restrictive covenants: Empirical investigation of public bond issues. Journal of 
Corporate Finance, 27, 251-268. https://doi.org/10.1016/j.jcorpfin.2014.05.011

Smith, C. \& Warner, J. (1979). On financial contracting: An analysis of bond covenants. Journal of Financial Economics ,7, 117-161. https://doi.org/10.1016/0304-405X(79)90011-4

Simpson, D. (1973). The Drafting of Loan Agreements: A Borrower's Viewpoint. Business Lawyer, 29, 1161-1196.

Torabzadeh, K., Roufagalas, J. \& Woodruff, C. (2000). Self-selection and the effects of poison put/call covenants on the reoffering yields of corporate bonds. International Review of Economics and Finance, 9, 139-156. https://doi.org/10.1016/S1059-0560(99)00050-7

\section{Notes}

Note 1. Our sample includes bonds with zero covenants according to the covenant information in FISD database.

Note 2. Performance-sensitive pricing provisions are generally included in contracts of bank loans, not contracts of public bonds. Hence, we do not consider performance-sensitive pricing provisions in this paper.

Note 3. Debt restrictions include negative pledge, subsidiary guarantee, leverage test, net earnings test, maintenance of net worth, and restrictions on funded debt, issuance of subordinated debt, maximum indebtedness and borrowing.

Note 4. Debt priority restrictions include restrictions on senior debt issuance and liens.

Note 5. Direct investment restrictions include restrictions on risky investments and stock transfer.

Note 6. Indirect investment restrictions include restrictions on fixed charge coverage, transactions with affiliates, subsidiary redesignation and after acquired property clause.

Note 7. Default related event covenants include declining net worth trigger/percentage/provisions, cross default, cross acceleration, voting power percentage and rating decline trigger/provision.

Note 8. See Greene, William H., Econometric Analysis (fifth edition), Prentice Hall, 2003, 736-740 for more details. 